\title{
Photochemical transformations of riverine dissolved organic matter: effects on estuarine bacterial metabolism and nutrient demand
}

\author{
Erik M. Smith*, Ronald Benner \\ University of South Carolina, Department of Biological Sciences and Marine Science Program, Columbia, \\ South Carolina 29208, USA
}

\begin{abstract}
By experimentally simulating the exposure of terrigenous dissolved organic matter (DOM) to sunlight during the mixing of river water and seawater in an estuary (St. Helena Sound, South Carolina), this study examined how photochemical alterations may affect both the magnitude and fate of DOM utilization by estuarine bacteria. In a series of experiments performed with water samples collected from 3 blackwater rivers draining into an estuary of the South Atlantic Bight (USA), exposure to light resulted in significant decreases in dissolved organic carbon (DOC) concentration and DOM absorption at $350 \mathrm{~nm}$ relative to dark controls. When these water samples were subsequently inoculated with an estuarine bacterial community, prior exposure to light significantly increased bacterial growth, respiration and total DOC consumption relative to that observed in control treatments. Increases in respiration (46 to $78 \%$ ) were, however, always greater than increases in growth (19 to $35 \%$ ). This resulted in decreases in bacterial growth efficiency that ranged from 16 to $33 \%$ and appeared predictable from initial differences in DOM optical characteristics. In addition, although light exposure consistently resulted in significant $\mathrm{NH}_{4}$ production, bacterial metabolism in light treatments was accompanied by a significant increase in bacterial demand for inorganic nutrients (117 to $243 \%$ over dark controls). These results indicate that irradiation of terrigenous DOM significantly alters its ultimate fate $\left(\mathrm{CO}_{2}\right.$ vs. bacterial biomass) and that bacterial carbon metabolism of photoaltered DOM is coupled to an enhanced demand for inorganic nutrients, which may considerably influence ecosystem-scale carbon and nutrient interactions in the coastal zone.
\end{abstract}

KEY WORDS: Bacterial production - Respiration - Growth efficiency · Photochemical effects · Organic carbon · Blackwater rivers

\section{INTRODUCTION}

Riverine transport of dissolved organic matter (DOM) forms an important link between terrestrial and marine ecosystems. Global river discharge of dissolved organic carbon (DOC) is estimated at $0.25 \times 10^{15} \mathrm{~g} \mathrm{C}$ $\mathrm{yr}^{-1}$, which represents a significant term in oceanic carbon budgets (Hedges et al. 1997). Riverine DOM is also an important source of nutrients transported to the marine environment (Seitzinger \& Sanders 1997, Stepanauskas et al. 2002). The DOM load carried by many rivers appears to be primarily of vascular plant origin and has traditionally been considered largely resistant to biological degradation, yet isotopic and molecular analyses suggest that terrigenous sources of DOM comprise only a small fraction of the oceanic DOM pool (e.g. Opsahl \& Benner 1997, Hernes \& Benner 2002). The occurrence of net heterotrophy (total respiration > primary production) in many estuarine and coastal environments (Smith \& Hollibaugh 1993, Hopkinson \& Smith 2005) indicates that at least a portion of riverine DOM must be bioreactive and acting to subsidize the metabolism of these near-shore ecosystems.

Photochemical processes have considerable direct and indirect impacts on riverine DOM in the coastal zone (see recent reviews by Mopper \& Kieber 2002 and Moran \& Covert 2003). Exposure to sunlight has been 
shown to photomineralize a significant fraction of DOM directly to $\mathrm{CO}$ and $\mathrm{CO}_{2}$ (e.g. Gao \& Zepp 1998). Irradiation of DOM can also result in the photoproduction of inorganic nitrogen (Bushaw et al. 1996) and inorganic phosphorus (Francko \& Heath 1982, Vähätalo et al. 2003), but results are often contradictory (Grzybowski 2003). Although the photomineralization to inorganic carbon represents a loss of DOM potentially available to the microbial community, organic photoproducts are also known to occur. Photochemical processes structurally alter DOM, resulting in a reduction in average molecular weight (e.g. Opsahl \& Benner 1998, Brinkman et al. 2003) and the production of a number of specific, low-molecular-weight organic compounds (e.g. Kieber et al. 1990). Since photochemically altered DOM is often more readily available for microbial utilization (Moran \& Zepp 1997), this has led to the view that photooxidation of recalcitrant terrigenous DOM injects extra 'fuel' into coastal aquatic food webs (Mopper \& Kieber 2002).

It now appears that the origin and chemical composition of DOM has a large effect on its photoreactivity and, perhaps more importantly, on the subsequent bioavailability of the resulting photoproducts (Benner \& Biddanda 1998, Obernosterer et al. 1999, Tranvik \& Bertilsson 2001). Recently, Moran \& Covert (2003) synthesized data relating DOM origin to the effects irradiation has on the subsequent bacterial processing of that DOM. From this, they proposed a conceptual model whereby irradiation of terrigenous DOM will have a 'positive' effect on the subsequent bacterial processing of this material, while irradiation of freshly produced, algal-derived DOM will have a 'negative' effect on its subsequent bacterial processing. Although there are now a substantial number of studies that form the basis of this model, the vast majority of these have focused on either bacterial production (typically) or bacterial respiration (less frequently) as the measure of bacterial response to DOM irradiation. In contrast, few studies have assessed the response of both metabolic processes to irradiation of natural DOM samples (Amon \& Benner 1996, Reche et al. 1998, Vähätalo et al. 2003), and such studies specific to the fate of terrigenous material in the coastal zone do not currently exist.

Bacteria utilize DOM in anabolic reactions for biosynthesis (i.e. bacterial production, BP) and in catabolic reactions to generate ATP (i.e. bacterial respiration, BR). Bacterial growth efficiency (BGE) is a measure of carbon biomass synthesized relative to total carbon utilization $(\mathrm{BP} /[\mathrm{BP}+\mathrm{BR}])$, and thus describes the partitioning of total carbon flow between these 2 fundamental components of bacterial metabolism. Values for BGE in natural bacterial communities are highly variable, and it is likely that BP and BR are regulated by different controlling factors (del Giorgio \& Cole 1998). A thorough understanding of the photochemical effects on DOM utilization by bacteria therefore requires information on both anabolic and catabolic pathways within the bacterial community. Indeed, the extent to which photooxidation of terrigenous DOM injects extra fuel into microbial food web depends, in part, on the effect irradiation has on variations in BGE.

The objective of the current study was to determine how potential photochemical alterations of DOM simultaneously affect both the production and respiration of estuarine bacteria growing on terrigenous DOM. In so doing, this study further explores the effects of irradiation on the magnitude and fate of terrigenous DOC utilization by bacteria in the coastal zone. The approach taken was to experimentally simulate the exposure of terrigenous DOM to sunlight during the dilution of river water with seawater in estuarine and near-shore environments, and then to quantify, relative to dark controls, the subsequent effects on bacterial metabolism, DOC and nutrient utilization in a series of bacterial bioassays of both short $(\sim 36 \mathrm{~h})$ and long ( 28 d) duration. Since the bioassay approach isolates bacteria from potential sources of new DOC, these experiments assess only that pool of substrates present at the time of sampling. When attempting to understand the fate of terrigenous DOM carried to the coastal zone, this becomes an advantage, however, as this DOM is, by definition, isolated from its original source. Experimental results indicate irradiation of terrigenous DOM does not simply increase the magnitude of DOC utilization by the bacterial community, but also significantly alters its ultimate fate (i.e. $\mathrm{CO}_{2}$ vs. bacterial biomass), as well as greatly increasing bacterial demand for inorganic nutrients. This study demonstrates that the effects of terrigenous DOM irradiation on bacterial metabolism are more complex than previously suggested and that irradiation may also greatly influence the interaction of carbon and nutrient dynamics in the coastal zone.

\section{MATERIALS AND METHODS}

Study area and sample collection. Four experiments were conducted with water samples collected from the 3 rivers forming the drainage basin of St. Helena Sound, a largely undeveloped estuary of the South Carolina coast (Fig. 1). These rivers, the Ashepoo, the Combahee and the Edisto, are all highly colored 'blackwater' systems that drain the Atlantic Coastal Plain province. Their watersheds are covered primarily by pine and pine-hardwood forests, and each watershed contains extensive networks of forested wetlands 


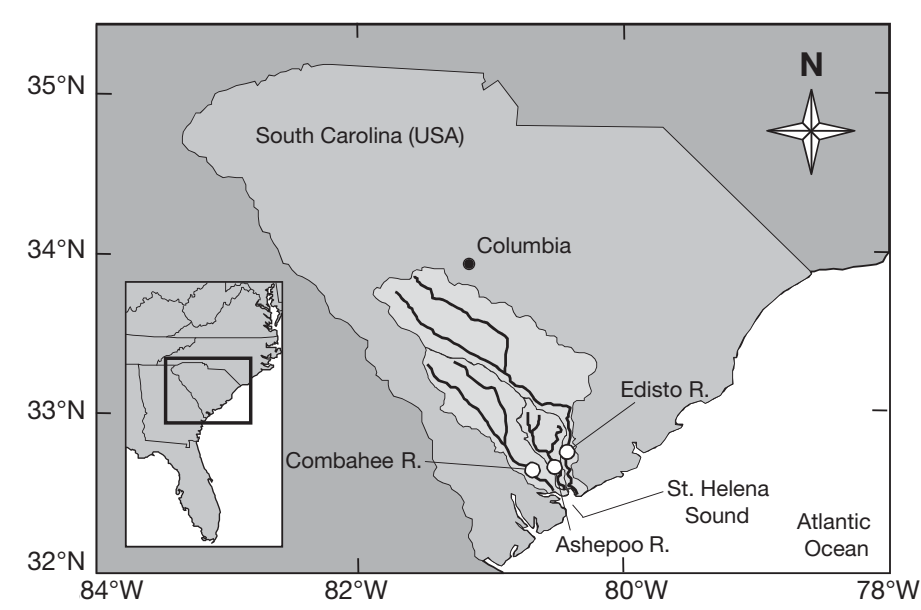

Fig. 1. Sampling locations in the 3 rivers (Ashepoo, Combahee, Edisto) of the St. Helena Sound, South Carolina, USA, shown with their respective watersheds

( $\sim 11 \%$ of watershed area for the Edisto and $\sim 18 \%$ of watershed area for both the Ashepoo and Combahee). The Edisto, the largest of the 3 rivers and the only one that has been gauged, has an average freshwater flow of $9.8 \times 10^{7} \mathrm{~m}^{3} \mathrm{yr}^{-1}$. The lower reaches of the Combahee and the Edisto, as well as almost the entire length of the Ashepoo, are contained within the ACE Basin National Estuarine Research Reserve.

Water samples from the 3 rivers were collected in the freshwater portion of the rivers, just above the head-oftide. The Edisto and Ashepoo were sampled on 27 August 2003. The Ashepoo was sampled a second time, along with the Combahee, on 31 October 2003. Henceforth, the Ashepoo sampling of 27 August will be referred to as 'Ashepoo 1' and the sampling of 31 October referred to as 'Ashepoo 2'. On each sampling occasions an estuarine bacterial community was also collected from the estuarine portion of the Ashepoo River (salinity $=11.5$ ). This served as the inoculum for the bacterial growth and biodegradation phase of the experiments for both of the 2 rivers sampled on that date.

From each sampling location 201 of water were transported in 501 acid-washed Nalgene carboys shielded from sunlight and returned to the laboratory within $4 \mathrm{~h}$ for subsequent filtering and experimental incubations. River water samples were filtered through pre-rinsed $0.2 \mu \mathrm{m}$ pore-size Nuclepore polyester tracketched membrane filter cartridges (Whatman QTEC). To isolate the estuarine bacterial community, estuarine water was filtered through a pre-rinsed $0.8 \mu \mathrm{m}$ poresize Nuclepore polyester track-etched membrane filter cartridge (Whatman QTEC).

DOM irradiation protocol. Aliquots of $0.2 \mu \mathrm{m}$ filtered river water samples $(700 \mathrm{ml})$ were placed in duplicate $1 \mathrm{l}$ quartz Erlenmeyer flasks and exposed to
$24 \mathrm{~h}$ irradiation in a Suntest XLS solar simulator (Atlas Electric Devices), which is equipped with a xenon lamp and a series of spectral filters that result in a light spectrum closely resembling that of natural sunlight. Light intensity during the incubations was $750 \mathrm{~W} \mathrm{~m}^{-2}$. The total light dose over the course of the incubation was $64800 \mathrm{~kJ} \mathrm{~m}^{-2}$. The quartz flasks were immersed in a recirculating water bath maintained at $20 \pm 1^{\circ} \mathrm{C}$. Experimental controls (dark treatments) were established by placing an equivalent portion of filtered river water in duplicate Pyrex Erlenmeyer flasks that were maintained at $20 \pm 2{ }^{\circ} \mathrm{C}$ in the dark for $24 \mathrm{~h}$. Immediately prior to and following incubations, subsamples were collected for determinations of DOC and nutrient concentrations as well as DOM optical properties. The remaining water was used as media for bacterial growth and biodegradation assays (below).

Bacterial growth and biodegradation protocol. River water from both the irradiated and dark treatments was diluted 1:1 with $0.2 \mu \mathrm{m}$ filtered artificial seawater (Sigma), resulting in a final salinity of $\sim 14 \mathrm{psu}$, and inoculated (5\% final volume) with an estuarine bacterial community $(0.8 \mu \mathrm{m}$-filtered estuarine water). A portion of the sample water mixture was then aliquotted into eight $60 \mathrm{ml}$ biological oxygen demand (BOD) bottles for each of the irradiated treatments and dark controls. This time-series approach using replicated incubation bottles has been successfully used previously (e.g. Moran et al. 1999, Hopkinson et al. 2002). The remaining water was transferred into 11 polycarbonate (PC) bottles. The BOD bottles were incubated in the dark while submerged in a water bath maintained at $24 \pm 1^{\circ} \mathrm{C}$. The PC bottles were incubated in the dark in an incubation chamber maintained at $24 \pm 1^{\circ} \mathrm{C}$.

At time zero and then again at intervals of 4 to $8 \mathrm{~h}$ for the first $\sim 36 \mathrm{~h}, 1$ BOD bottle from each replicate incubation was fixed with Winkler reagents for the determination of $\mathrm{O}_{2}$ concentration. In parallel with $\mathrm{O}_{2}$ sampling, a $5 \mathrm{ml}$ subsample was drawn from each PC bottle and fixed with cold, particle-free glutaraldehyde ( $1 \%$ final concentration) for the determination of bacterial abundance. In addition, each PC bottle was subsampled at Time zero and then again after approximately $1.5,3,5,7,10,14,21$ and $28 \mathrm{~d}$ of incubation for determination of DOC and nutrient concentrations.

Analytical methods. Concentrations of dissolved $\mathrm{O}_{2}$ were determined by automated Winkler titration using a Mettler DL21 titrator equipped with an automated potentiometric end-point detection system. Concentrations of DOC and total nitrogen (TN) were measured by high temperature oxidation using a Shimadzu TOC$\mathrm{V}$ carbon analyzer equipped with a chemiluminescence (N) detector (Shimadzu TNM-1). DOC/TN samples $(15 \mathrm{ml})$ were acidified with $10 \% \mathrm{HCl}$ (to 
$\mathrm{pH}$ 2.5), stored in combusted, Teflon-capped glass vials at $4^{\circ} \mathrm{C}$ in the dark, and analyzed within 2 mo of collection. Samples $(30 \mathrm{ml})$ for total phosphorus (TP) and inorganic phosphorus $\left(\mathrm{PO}_{4}\right)$ were stored at $-20^{\circ} \mathrm{C}$ in the dark and analyzed within 1 mo of collection. Concentrations of $\mathrm{PO}_{4}$ were determined as soluble reactive phosphorus (SRP) by the molybdate blue colorimetric method (Parsons et al. 1984). Concentrations of TP were measured as SRP after UV oxidation (Armstrong et al. 1966). Concentrations of dissolved organic phosphorus (DOP) were calculated as the difference between TP and $\mathrm{PO}_{4}$. Samples $(5 \mathrm{ml})$ for nitrate plus nitrite $\left(\mathrm{NO}_{2+3}\right)$ were acidified with $10 \% \mathrm{HCl}$ (to $\mathrm{pH} 2.5$ ), stored at $4^{\circ} \mathrm{C}$ in the dark, and analyzed within 2 mo of collection. Concentrations of $\left(\mathrm{NO}_{2+3}\right)$ were determined by vanadium reduction and chemiluminescence detection using an Antek Model 7020 nitric oxide analyzer. Samples $(25 \mathrm{ml})$ for ammonia $\left(\mathrm{NH}_{4}\right)$ were analyzed immediately after collection by the phenol-hypoclorite method (Solórzano 1969). Concentrations of dissolved organic nitrogen (DON) were calculated as the difference between TN and inorganic $\mathrm{N}\left(\mathrm{NO}_{2+3}\right.$ plus $\left.\mathrm{NH}_{4}\right)$.

DOM absorbance at $350 \mathrm{~nm}$ wavelength was determined with a Shimadzu 1601 spectrophotometer using a $1 \mathrm{~cm}$ quartz cuvette. Absorbance was measured against Milli-Q water as the blank. Absorption coefficients $\left(a_{350}, \mathrm{~m}^{-1}\right)$ were calculated as $a_{350}=(D \times \operatorname{Ln} 10) / L$, where $D$ is the absorbance at $350 \mathrm{~nm}$ wavelength and $L$ is the path length (m) of the cuvette (Hu et al. 2002).

Bacterial cell numbers were quantified by epifluorescence microscopy (Porter \& Feig 1980). Immediately after sampling, a $4 \mathrm{ml}$ subsample was placed into a darkened filtering tower, stained with 4',6-diamidino2 phenylindole (DAPI; Sigma Chemical) at a final concentration of $25 \mathrm{\mu g} \mathrm{ml}^{-1}$ for $10 \mathrm{~min}$, then filtered onto a $25 \mathrm{~mm}$ diameter, $0.2 \mu \mathrm{m}$ pore-size black polycarbonate membrane filter (Poretics) under low vacuum. Filters were mounted in immersion oil (Resolve) on glass slides and examined at a final magnification of $1250 \times$ with an Olympus BX41 microscope equipped with reflected fluorescence unit and a $100 \mathrm{~W}$ mercury lamp. DAPI fluorescing cells were visualized using a UV filter set (excitation $360 \mathrm{~nm}$, barrier $460 \mathrm{~nm}$ ) and counted on a minimum of 20 random fields.

Data calculations for bacterial growth and biodegradation phase. Estimates of bacterial specific growth rate $\left(\mu, \mathrm{d}^{-1}\right)$, cell-specific respiration rate $(R$ cell $^{-1}$, fmol $\mathrm{O}_{2}$ cell $^{-1} \mathrm{~d}^{-1}$ ), bacterial growth efficiency $(\mathrm{BGE}, \%)$ and total bacterial carbon demand (BCD, umol C $\mathrm{l}^{-1} \mathrm{~d}^{-1}$ ) were calculated using bacterial cell abundance and $\mathrm{O}_{2}$ data. Values for $\mu$ were estimated as the slope of the natural log of bacterial abundance versus time, starting at time $(t)=0$ and until signs of departure from exponential growth were observed. Values for $R$ cell $^{-1}$ were estimated as the slope of the change in $\mathrm{O}_{2}$ versus the change in cell abundance over the period of exponential growth divided by time. Values for BGE were estimated as the slope of bacterial production versus the sum of bacterial production plus respiration. Bacterial production was taken to be the rate of change in cell abundance assuming a cellular carbon content of $20 \mathrm{fg} \mathrm{C}$ cell $^{-1}$ (Lee \& Fuhrman 1987). Respiration was taken to be the rate of change in $\mathrm{O}_{2}$ concentration converted to $\mathrm{C}$ units assuming a respiratory quotient of 1 (del Giorgio \& Cole 1998, Moran et al. 2000). Both measures were thus converted to a common unit and the linear regression allowed for the use of all data points measured during regrowth in the calculation of BGE, which was linear over the period of exponential growth. Values for BCD were estimated as the linear regression of the sum of bacterial production and respiration versus time for the linear portion of the re-growth curve.

Kinetics of DOC loss during the bacterial growth and biodegradation phase of the experiments were modeled using both the standard 1st-order exponential decay model, which assumes a single pool of reactive DOC, and a 2-pool 'multi-G' model (Berner 1980) that represents the decomposition of DOC as the simultaneous loss of 2 discrete pools of DOC each with differing inherent decay rates. The form of this latter model is:

$$
C_{t}=C_{1} \mathrm{e}^{-k_{1} t}+C_{2} \mathrm{e}^{-k_{2} t}
$$

where $C_{t}$ is the DOC concentration at time $t, C_{1}$ is the size of the 1 st DOC pool, $C_{2}$ is the size of the 2nd DOC pool, and $k_{1}$ and $k_{2}$ are the instantaneous decay rates of the $C_{1}$ and $C_{2}$ pools, respectively.

Statistical analyses. Nonlinear curve fitting of DOC kinetics were performed using the Gauss-Newton least-squares method. The significance of treatment effects among individual river samples and rivertreatment interaction effects for both the photoalteration and bacterial growth and biodegradation phases of the experiments was assessed using a $2 \times 4$ factorial analysis of variance (ANOVA) followed by means comparisons using the Tukey-Kramer honestly significant difference (HSD) test at the $\mathrm{p}<0.05$ level of significance. All curve fitting and statistical analyses were performed using JMP 5.0 statistical software (SAS Institute).

\section{RESULTS}

\section{Initial conditions of river water}

Concentrations of DOC varied significantly (ANOVA, $\mathrm{p}<0.05$ ) among the 4 river samples, ranging from 1.4 to $3.1 \mathrm{mmol} \mathrm{C}^{-1}$ (Table 1). Concentrations of DOC were high relative to both $\mathrm{TN}$ and $\mathrm{TP}$, with 
Table 1. Means (ranges) of initial conditions and treatment effects on carbon, nitrogen and phosphorus concentrations of duplicate $0.2 \mu \mathrm{m}$ filtered river water samples exposed to either $24 \mathrm{~h}$ darkness (dark treatment) or $24 \mathrm{~h}$ simulated sunlight (irradiated treatment). Dissolved organic nitrogen and phosphorus (DON and DOP) were determined by difference between total concentrations and inorganic concentrations. ${ }^{*}$ : treatment means are significantly different $(\mathrm{p}<0.05)$ from initial values, for within river comparisons only. DOC: dissolved organic carbon

\begin{tabular}{|c|c|c|c|c|c|c|}
\hline $\begin{array}{l}\text { River } \\
\text { Treatment }\end{array}$ & $\begin{array}{c}\text { DOC } \\
\left(\mu \mathrm{mol} \mathrm{l}^{-1}\right)\end{array}$ & $\begin{array}{c}\text { DON } \\
\left(\mu \mathrm{mol} \mathrm{l}^{-1}\right)\end{array}$ & $\begin{array}{c}\mathrm{NH}_{4} \\
\left(\mu \mathrm{mol} \mathrm{l} l^{-1}\right)\end{array}$ & $\begin{array}{c}\mathrm{NO}_{2+3} \\
\left(\mu \mathrm{mol} \mathrm{l}^{-1}\right)\end{array}$ & 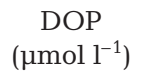 & $\begin{array}{c}\mathrm{PO}_{4} \\
\left(\mu \mathrm{mol} \mathrm{l}^{-1}\right)\end{array}$ \\
\hline \multicolumn{7}{|l|}{ Edisto } \\
\hline Initial & $1803(11)$ & 38.5 (2.9) & $2.6(0.0)$ & $7.4(0.1)$ & $0.6(0.0)$ & $1.7(0.0)$ \\
\hline Dark & $1786(23)$ & $38.3(1.4)$ & $2.6(0.2)$ & $7.4(0.1)$ & $0.7(0.0)$ & $1.7(0.0)$ \\
\hline Irradiated & $1635(42)^{*}$ & $36.8(0.6)$ & $4.7(0.3)^{*}$ & $7.5(0.1)$ & $0.6(0.1)$ & $1.7(0.0)$ \\
\hline \multicolumn{7}{|l|}{ Ashepoo 1} \\
\hline Initial & 3067 (18) & $57.9(1.2)$ & $2.8(0.1)$ & $1.4(0.1)$ & $0.7(0.1)$ & $2.5(0.0)$ \\
\hline Dark & 2999 (46) & $56.4(1.0)$ & $2.9(0.1)$ & $1.4(0.0)$ & $0.8(0.1)$ & $2.5(0.0)$ \\
\hline Irradiated & $2767(46)^{*}$ & $55.8(0.2)$ & $4.1(0.1)^{*}$ & $1.5(0.0)$ & $0.7(0.0)$ & $2.6(0.0)$ \\
\hline \multicolumn{7}{|l|}{ Combahee } \\
\hline Initial & $1438(11)$ & $31.6(0.3)$ & $1.5(0.1)$ & $1.1(0.0)$ & $0.4(0.0)$ & $1.3(0.0)$ \\
\hline Dark & $1440(7)$ & $32.1(0.3)$ & $1.2(0.6)$ & $1.1(0.0)$ & $0.4(0.0)$ & $1.3(0.1)$ \\
\hline Irradiated & $1293(9)^{*}$ & $30.6(0.6)^{*}$ & $2.8(0.2)^{*}$ & $1.1(0.0)$ & $0.4(0.0)$ & $1.3(0.0)$ \\
\hline \multicolumn{7}{|l|}{ Ashepoo 2} \\
\hline Initial & $1701(2)$ & $31.4(0.1)$ & $1.1(0.3)$ & $0.1(0.0)$ & $0.6(0.0)$ & $1.4(0.0)$ \\
\hline Dark & $1701(2)$ & $31.5(0.6)$ & $1.3(0.6)$ & $0.1(0.0)$ & $0.6(0.0)$ & $1.4(0.0)$ \\
\hline Irradiated & $1409(5)^{*}$ & $29.5(0.9)^{*}$ & $3.1(0.1)^{*}$ & $0.1(0.1)$ & $0.6(0.0)$ & $1.5(0.0)$ \\
\hline
\end{tabular}

atomic $\mathrm{C}: \mathrm{N}$ ratios ranging from 37 to 52 and atomic $\mathrm{C}: \mathrm{P}$ ratios ranging from 784 to 958 . There was also a distinct difference among river samples in the distributions of $\mathrm{N}$ and $\mathrm{P}$ with respect to organic and inorganic forms of the nutrients. While most of the TN in the samples was in the form of DON (mean \% DIN $=10$, range $=4$ to 21), most of the TP was in the form of dissolved inorganic phosphorus (DIP) (mean $\% \mathrm{PO}_{4}=74$, range $=69$ to 78 ) .

Absorption coefficients $\left(a_{350}, \mathrm{~m}^{-1}\right)$ varied with DOC concentration among river samples $(\mathrm{r}=0.99, \mathrm{n}=4, \mathrm{p}<$ 0.001 ), with initial values of $a_{350}$ ranging from 41.2 to $55.5 \mathrm{~m}^{-1}$. Variability of $a_{350}$ was greater than that of DOC (coefficient of variation, $\mathrm{CV}$, of 51 and $36 \%$, respectively), such that carbon-normalized absorption coefficients showed slight, but significant $(p<0.05)$, variability among river samples (Table 2).

\section{Effects of irradiation}

Exposure of river water to simulated sunlight resulted in a significant decrease in DOC concentration (Table 1). Loss of DOC by photomineralization in irradiated treatments amounted to $9-17 \%$ of the initial pool size across the 4 experiments. In contrast, no significant loss of DOC was observed for any of the dark treatments. Decreases in DOC in the irradiated treatments were accompanied by decreases in $a_{350}$ (Table 2). The magnitude of this decrease varied significantly among the 4 experiments and appeared to be related to the initial $a_{350}$ value of the river water $\left(\Delta a_{350}=-0.16 \times\left[\right.\right.$ initial $\left.a_{350}\right]-7.2 ; \mathrm{n}=8, \mathrm{r}^{2}=0.76 ; \mathrm{p}<$ 0.01). Although changes in $a_{350}$ were significantly correlated to changes in DOC concentration $(r=0.93$,

Table 2. Means (ranges) of initial conditions and treatment effects on dissolved organic matter (DOM) optical properties of duplicate $0.2 \mu \mathrm{m}$ filtered river water samples exposed to either $24 \mathrm{~h}$ darkness (dark treatment) or $24 \mathrm{~h}$ simulated sunlight (irradiated treatment). $a_{350}$ : absorption coefficient at 350 $\mathrm{nm} ; a_{350}$ /DOC: dissolved organic carbon-normalized absorption coefficient. * : treatment means are significantly different $(p<0.05)$ from initial values, for within-river comparisons only

\begin{tabular}{|lcc|}
\hline $\begin{array}{l}\text { River } \\
\text { Treatment }\end{array}$ & $\begin{array}{c}a_{350} \\
\left(\mathrm{~m}^{-1}\right)\end{array}$ & $\begin{array}{c}a_{350} / \mathrm{DOC} \\
\left(a_{350}\left[\mathrm{mmol} \mathrm{C}^{-1}\right]^{-1}\right)\end{array}$ \\
\hline Edisto & & \\
Initial & $55.5(0.0)$ & $30.8(0.2)$ \\
Dark & $55.7(0.5)$ & $31.2(0.7)$ \\
Irradiated & $41.8(0.5)^{*}$ & $25.5(1.0)^{*}$ \\
Ashepoo 1 & & \\
Initial & $117.3(0.1)$ & $38.2(0.2)$ \\
Dark & $117.1(0.1)$ & $39.1(0.6)$ \\
Irradiated & $91.3(2.2)^{*}$ & $33.0(0.3)^{*}$ \\
Combahee & & \\
Initial & $41.2(0.0)$ & $28.6(0.2)$ \\
Dark & $41.9(0.0)^{*}$ & $29.1(0.2)$ \\
Irradiated & $29.0(0.1)^{*}$ & $22.4(0.3)^{*}$ \\
Ashepoo 2 & & \\
Initial & $53.7(0.0)$ & $31.5(0.0)$ \\
Dark & $54.0(0.2)$ & $31.8(0.1)$ \\
Irradiated & $33.6(0.9)^{*}$ & $23.8(0.7)^{*}$ \\
\hline
\end{tabular}


$\mathrm{n}=8, \mathrm{p}<0.001$ ), the loss of $a_{350}$, which amounted to $22-37 \%$ of initial values, was greater than the corresponding relative loss of DOC. As a result, the Cspecific $a_{350}$ of the remaining DOC pool also decreased significantly in the irradiated treatments. Values for both $a_{350}$ and $a_{350}(\mathrm{DOC})^{-1}$ in dark treatments were not significantly different from initial values in any of the experiments.

Exposure of river water to simulated sunlight also resulted in a significant increase in $\mathrm{NH}_{4}$ concentrations. This photochemical production of $\mathrm{NH}_{4}$ was small relative to DON concentrations in all experiments, but represented an 80 to $180 \%$ increase in the initial $\mathrm{NH}_{4}$ pool size. $\mathrm{NH}_{4}$ concentrations in the dark treatments, however, were never significantly different from the initial values. There were no significant changes in the concentrations of $\mathrm{NO}_{2+3}$ or $\mathrm{PO}_{4}$ in either the irradiated or dark treatments in any of the experiments.

\section{Effects of photochemical transformations on bacterial metabolism}

When an estuarine bacterial community was introduced to river water samples, the inoculum underwent exponential growth in both the irradiated and dark treatments of all 4 experiments, with some cultures showing signs of reduced growth rates after $\sim 24 \mathrm{~h}$ (Fig. 2). No evidence of the growth of bacterial grazers was observed during this time. Estimates of bacterial metabolism derived from the raw cell abundance and $\mathrm{O}_{2}$ data, however, showed that exposure of riverine DOM to simulated sunlight increased rates of bacterial cell production and respiration, and also significantly altered the balance between these 2 pathways of bacterial metabolism (Fig. 3).

In the dark treatments, intrinsic growth rates $(\mu)$ for the 4 experiments averaged $2.0 \mathrm{~d}^{-1}$, with a range of 1.6 to $2.5 \mathrm{~d}^{-1}$. Values for $\mu$ increased to a mean of $2.6 \mathrm{~d}^{-1}$ (range $=1.9$ to $3.1 \mathrm{~d}^{-1}$ ) in the light treatments, and in all experiments except that of the river Edisto $\mu$ was significantly greater (ANOVA, p < 0.05) in the irradiated treatment than the dark treatment (Fig. 3a). The lack of a significant difference in $\mu$ for the Edisto experiment could be attributable to the low power of the statistical test arising from the small sample size $(\mathrm{n}=2)$ for each treatment. Statistically significant differences could be resolved, however, if the bacterial abundance data were pooled across replicates and the $95 \%$ confidence limits for the slope of the natural log of cell abundance versus time (used to derive $\mu$ ) were compared between irradiated and dark treat-
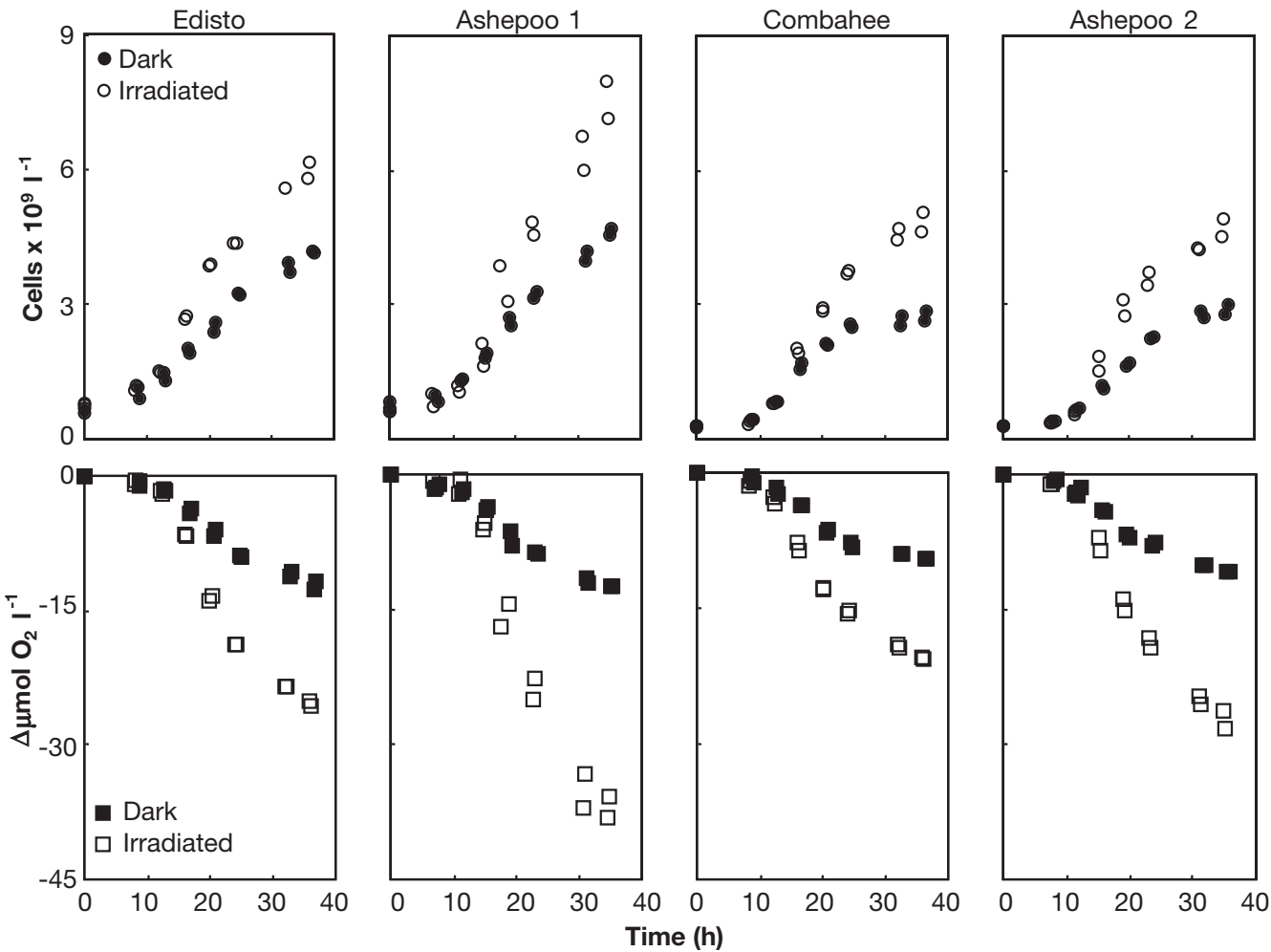

Fig. 2. Changes in bacterial abundance and $\mathrm{O}_{2}$ concentration versus incubation time in duplicate irradiated and dark treatments of the 4 experimental cultures 

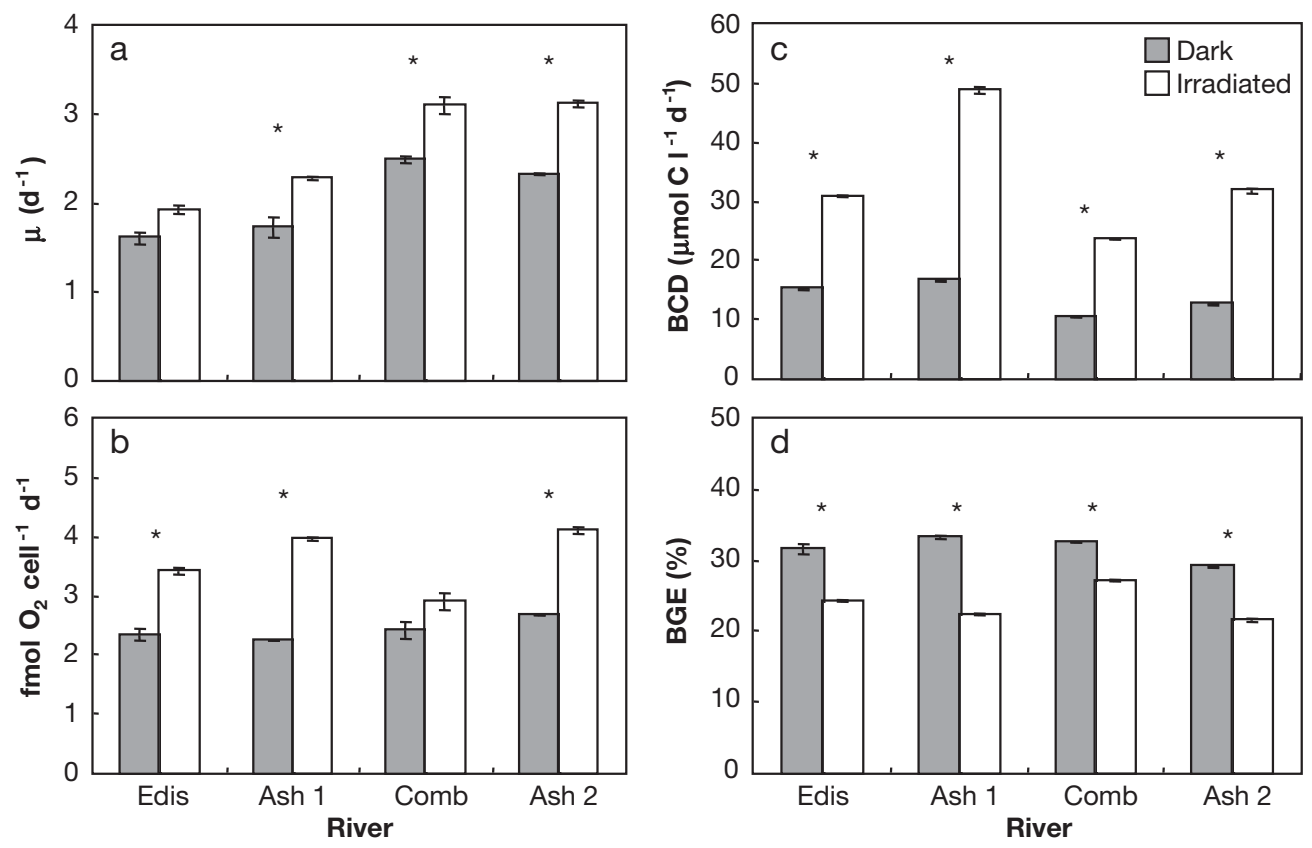

Fig. 3. Treatment comparisons for (a) intrinsic growth rate $(\mu)$, (b) cell-specific respiration rate $\left(R\right.$ cell $\left.^{-1}\right)$, (c) bacterial carbon demand (BCD), and (d) bacterial growth efficiency (BGE). Vertical bars: range of duplicate cultures. *: within-river treatment pairs significantly different at $\mathrm{p}<0.05$. Edis: Edisto; Ash: Ashepoo; Comb: Combahee

ments. Thus, irradiation of river water samples significantly increased $\mu$ by an average of $28 \%$ (range $=19$ to $35 \%$ ) relative to dark treatments, across all experiments.

Cell-specific respiration rates $\left(R\right.$ cell $\left.^{-1}\right)$ of the bacteria were similar among the dark treatments of all experiments, with a mean of $2.4 \mathrm{fmol} \mathrm{O}_{2}$ cell $^{-1} \mathrm{~d}^{-1}$ and a range of 2.3 to $2.7 \mathrm{fmol} \mathrm{O}_{2}$ cell $^{-1} \mathrm{~d}^{-1}$. In the irradiated treatments, $R$ cell $^{-1}$ increased to a mean of $3.6 \mathrm{fmol} \mathrm{O}_{2}$ cell $^{-1} \mathrm{~d}^{-1}$ and displayed a greater range in values (2.9 to $4.1 \mathrm{fmol} \mathrm{O}_{2}$ cell $^{-1} \mathrm{~d}^{-1}$ ) relative to the dark treatments (CV of $15.5 \%$ compared with a CV of $7.9 \%$ ). Irradiation increased $R$ cell $^{-1}$ by an average of $49 \%$ (range $=20$ to $78 \%$ ) relative to dark treatments, across all experiments (Fig. 3b). Interestingly, in comparison to the relatively low variability among dark treatments across experiments, the degree to which irradiation enhanced $R$ cell $^{-1}$ (expressed as a \% increase in the irradiated treatment over the dark treatment) was more variable $(\mathrm{CV}=50 \%)$ than for any other measure of bacterial metabolism (CVs of 25 to $28 \%$ ).

Increases in both bacterial growth and respiration with exposure of DOM to simulated sunlight resulted in profoundly increased rates of total BCD relative to the dark treatments (Fig. 3c). BCD was estimated to be

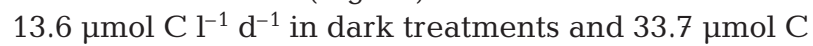
$\mathrm{l}^{-1} \mathrm{~d}^{-1}$ in irradiated treatments. This increase with irra- diation was highly significant in all experiments and resulted in BCD values that were 104 to $196 \%$ higher than corresponding values in dark treatments. Although irradiation stimulated both $\mu$ and $R$ cell $^{-1}$, greater increases in $R$ cell $^{-1}$ (mean increase of $49 \%$ ) than in $\mu$ (mean increase of $28 \%$ ) significantly altered the ultimate fate of the utilized DOM, as indicated by BGE (Fig. 3d). Values of BGE ranged from 29 to $33 \%$ in dark treatments, and they decreased significantly in all irradiated treatments, ranging from 22 to $27 \%$.

The effects of exposure to simulated sunlight (irradiated versus dark treatment comparisons) were not statistically independent of the source of river water, as indicated by results of the $2 \times 4$ factorial analyses. Treatment $\times$ river interaction effects were significant for all 4 metabolic parameters (at the $p<0.05$ level for $\mu$, and at the $\mathrm{p}<0.0001$ level for $R$ cell $^{-1}, \mathrm{BCD}$ and BGE). In particular, the initial $a_{350}$ value of riverine DOM appeared to be a strong predictor of the magnitude of the subsequent change in both BCD and BGE (expressed as a \% change in irradiated treatment over dark treatment) observed among the 4 experiments (Fig. 4). These changes in BCD and BGE could also be predicted by the decrease in $a_{350}$ with increasing irradiation since, as described above, initial $a_{350}$ values were a strong predictor of the magnitude by which they would decrease with exposure to simulated sunlight. 

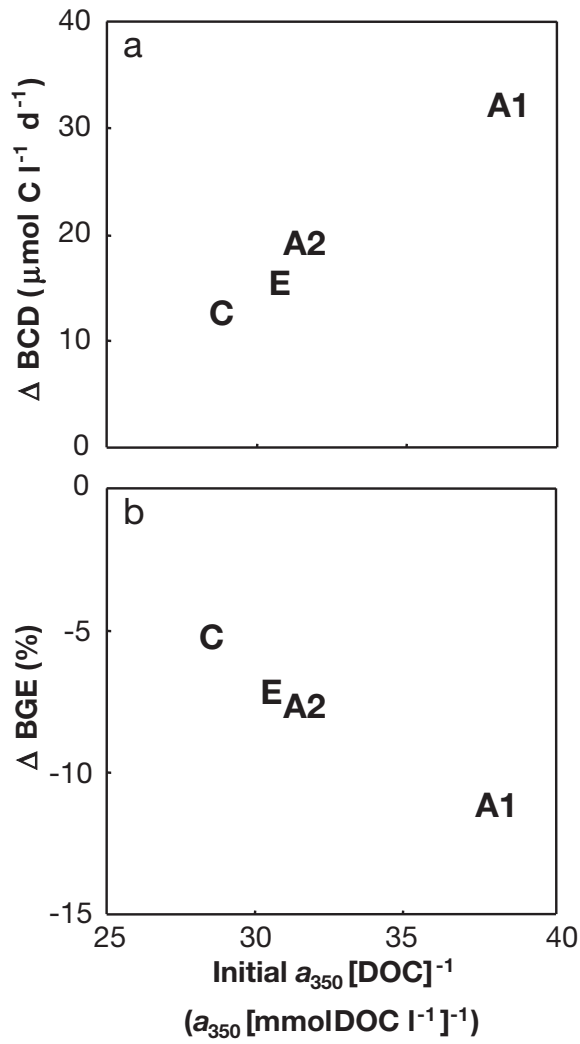

Fig. 4. Mean $(\mathrm{n}=2)$ changes in (a) bacterial carbon demand $(\triangle \mathrm{BCD})$ and $(\mathrm{b})$ bacterial growth efficiency $(\triangle \mathrm{BGE})$, expressed as difference between irradiated and dark treatments, plotted against DOC-specific absorption coefficients prior to irradiation for each of the 4 river samples in 2003: A1, A2 = Ashepoo on 27 August and 31 October, respectively; $\mathrm{C}=$ Combahee on 31 October $; \mathrm{E}=$ Edisto on 27 August. $a_{350}$ : absorption coefficient

\section{Effects of photochemical transformations on carbon and nutrient dynamics}

In addition to rates of bacterial metabolism measured in the first $\sim 36 \mathrm{~h}$, longer-term changes in DOC and inorganic $\mathrm{N}$ and $\mathrm{P}$ concentrations due to exposure to simulated sunlight were quantified by extending incubations to $\sim 28 \mathrm{~d}$. Changes in irradiated and dark treatments from the Ashepoo 1 experiment, which showed the greatest differences between treatments, are presented as an example in Fig. 5.

Measurable loss of DOC was observed in both irradiated and dark treatments of each experiment, but the magnitude of this loss was significantly greater in the irradiated treatments, when compared over either 5 or $28 \mathrm{~d}$ of incubation (Table 3). Differences in the magnitude of DOC loss were compared on a percentage basis, to account for differences in starting concentrations (as a result of photomineralization of DOC during initial exposure to simulated sunlight). The \% loss of DOC in the first $5 \mathrm{~d}$ of incubation was rather small in the dark treatments, with mean losses ranging from $2.4-5.4 \%$, but this increased to $19.0-24.2 \%$ after $28 \mathrm{~d}$. By comparison, \% loss of DOC in the first $5 \mathrm{~d}$ of incubation in the irradiated treatments ranged from $8.4-19.5 \%$, and this increased to $26-38.9 \%$ after $28 \mathrm{~d}$.

Differences in DOC degradation among experiments and treatments followed a pattern similar to that observed for BCD estimates for the first $\sim 36 \mathrm{~h}$. Indeed, linearized DOC loss rates over the first $5 \mathrm{~d}$ of incubation were significantly correlated with BCD $(n=16, r=$
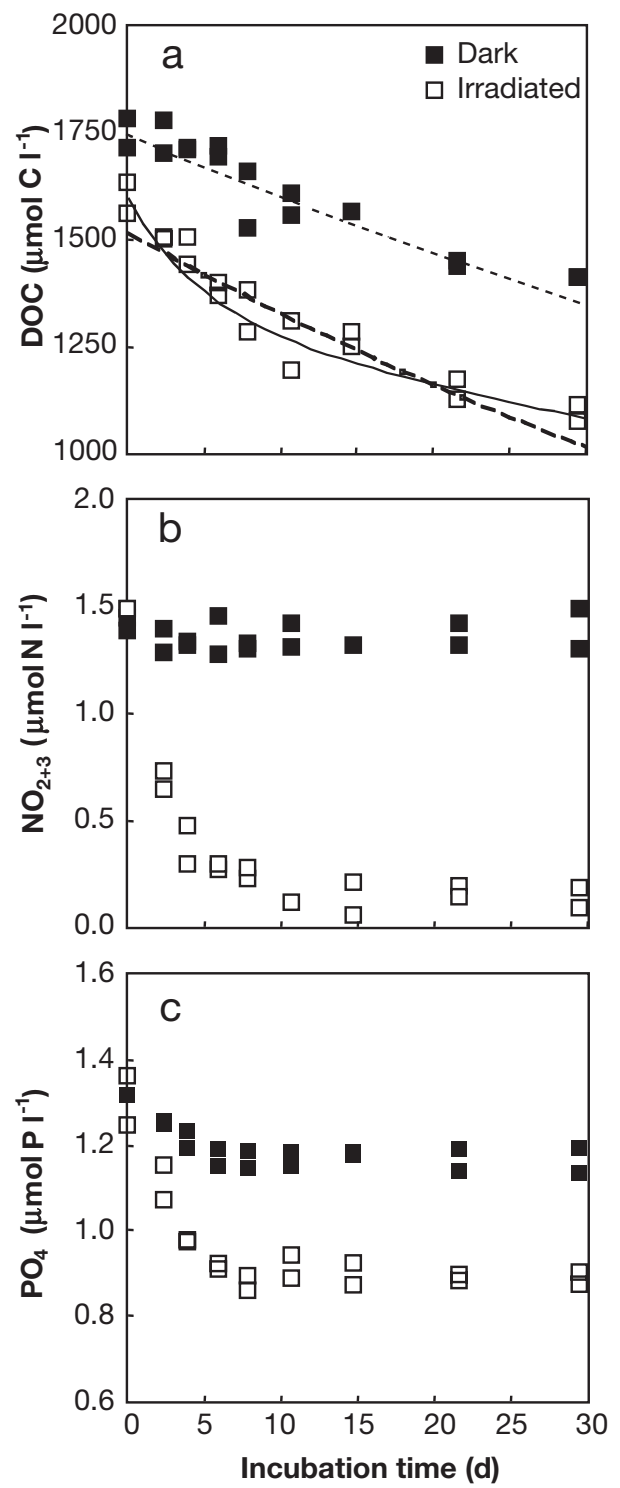

Fig. 5. Time-course changes in (a) DOC, (b) $\mathrm{NO}_{2+3}$ and (c) $\mathrm{PO}_{4}$ concentrations during bacterial re-growth in duplicated irradiated and dark treatments for Ashepoo 1 river water experiments. In (a), dashed line is the fitted negative exponential model of DOC loss in the dark treatment; the dashed line is the fitted negative exponential model of DOC loss in the irradiated treatment; the continuous line is the fitted 2-pool multi-G model of DOC loss in the irradiated treatment 
0.86) and the slope of the relationship was not significantly different from 1 ( $p<0.05)$. Over the $28 \mathrm{~d}$ timecourse, however, decay coefficients $(k)$ for DOC loss in dark treatments were best described as a simple exponential decay function (Table 3). Similarly, calculated decay coefficients for DOC losses were greater in the irradiated treatments than the dark treatments (Table 3), but did not fit the data as well (Fig. 5). A 2-pool 'multi-G' model was applied to capture the biphasic patterns visually evident in the DOC concentrations of the irradiated treatments (Fig. 5). In each experiment, this resulted in a better fit to the data.
Differences between irradiated and dark treatments were also evident for changes in concentrations of inorganic nutrients during the course of incubation (Table 4). Concentrations of $\mathrm{PO}_{4}$, the dominant form of $\mathrm{P}$ in all river water samples, decreased significantly in all dark treatments, with consumption in the first $5 \mathrm{~d}$ of incubation ranging from 6.7 to $17.6 \%$ of the intial values. This consumption more than doubled, however, in the irradiated treatments, with concentrations after $5 \mathrm{~d}$ ranging from 25.6 to $38.8 \%$ of the initial values. When these rates of $\mathrm{PO}_{4}$ decreases were matched with bacterial biomass production, $\mathrm{PO}_{4}$ demand per

Table 3. DOC removal in bacterial growth cultures of river water initially exposed to either $24 \mathrm{~h}$ darkness (dark treatment) or $24 \mathrm{~h}$ simulated sunlight (irradiated treatment). Initial concentrations and \% differences in DOC concentrations reported as means (and ranges) of duplicate cultures. Rate constants for DOC removal were derived from non-linear fit of either a simple exponential decay model $(k)$ or a 2-pool exponential decay model $\left(k_{1}\right.$ and $\left.k_{2}\right)$ using combined data from duplicate cultures $(\mathrm{n}=16)$. The 2-pool exponential decay model was applied only to irradiated treatments. $\Delta \mathrm{DOC}_{5}: \%$ of initial DOC consumed over $5 \mathrm{~d} . \Delta \mathrm{DOC} 28$ : $\%$ of initial DOC consumed after $28 \mathrm{~d}$

\begin{tabular}{|c|c|c|c|c|c|c|}
\hline $\begin{array}{l}\text { River } \\
\text { Treatment }\end{array}$ & 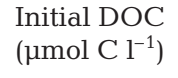 & $\begin{array}{c}k \\
\left(d^{-1}\right)\end{array}$ & $\begin{array}{c}k_{1} \\
\left(\mathrm{~d}^{-1}\right)\end{array}$ & $\begin{array}{c}k_{2} \\
\left(d^{-1}\right)\end{array}$ & $\begin{array}{c}\Delta \mathrm{DOC}_{5} \\
(\%)\end{array}$ & $\begin{array}{c}\Delta \mathrm{DOC}_{28} \\
(\%)\end{array}$ \\
\hline \multicolumn{7}{|l|}{ Edisto } \\
\hline Dark & $1168(82)$ & -0.010 & & & $3.5(4.3)$ & $24.2(4.3)$ \\
\hline Irradiated & $1126(6)$ & -0.016 & -0.076 & -0.004 & $9.4(6.0)$ & $35.0(1.7)$ \\
\hline \multicolumn{7}{|l|}{ Ashepoo 1} \\
\hline Dark & 1749 (69) & -0.009 & & & $2.4(2.4)$ & $19.3(3.0)$ \\
\hline Irradiated & $1598(73)$ & -0.013 & -0.208 & -0.007 & $11.3(2.1)$ & $33.7(6.7)$ \\
\hline \multicolumn{7}{|l|}{ Combahee } \\
\hline Dark & 1039 (29) & -0.009 & & & $4.4(2.2)$ & $21.6(1.4)$ \\
\hline Irradiated & 993 (5) & -0.011 & -0.070 & -0.003 & $8.4(3.9)$ & $26.0(2.2)$ \\
\hline \multicolumn{7}{|l|}{ Ashepoo 2} \\
\hline Dark & 945 (8) & -0.008 & & & $5.4(0.3)$ & $19.0(0.4)$ \\
\hline Irradiated & 796 (94) & -0.015 & -0.194 & -0.008 & $19.5(3.7)$ & $38.9(5.9)$ \\
\hline
\end{tabular}

Table 4. Initial concentrations and \% removal of inorganic nitrogen and phosphorus for bacterial growth cultures of river water initially exposed to either $24 \mathrm{~h}$ darkness (dark treatments) or $24 \mathrm{~h}$ simulated sunlight (irradiated treatments). All data are means (range) of duplicate incubations. Differences in concentrations were determined after $5 \mathrm{~d}$. nd: not determined

\begin{tabular}{|c|c|c|c|c|c|c|}
\hline $\begin{array}{l}\text { River } \\
\text { Treatment }\end{array}$ & $\begin{array}{c}\text { Initial } \mathrm{NH}_{4} \\
\left(\mu \mathrm{mol} \mathrm{N} \mathrm{l^{-1 }}\right)\end{array}$ & $\begin{array}{c}\Delta \mathrm{NH}_{4} \\
(\%)\end{array}$ & 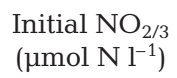 & $\begin{array}{c}\Delta \mathrm{NO}_{2 / 3} \\
(\%)\end{array}$ & $\begin{array}{l}\text { Initial } \mathrm{PO}_{4} \\
\left(\mu \mathrm{mol} \mathrm{P} \mathrm{l}^{-1}\right)\end{array}$ & $\begin{array}{c}\Delta \mathrm{PO}_{4} \\
(\%)\end{array}$ \\
\hline \multicolumn{7}{|l|}{ Edisto } \\
\hline Dark & nd & nd & $4.4(0.0)$ & $3.9(2.3)$ & $0.9(0.0)$ & $17.6(2.1)$ \\
\hline Irradiated & nd & nd & $4.6(0.1)$ & $6.4(6.7)$ & $0.9(0.0)$ & $38.8(1.4)$ \\
\hline \multicolumn{7}{|l|}{ Ashepoo 1} \\
\hline Dark & nd & nd & $1.4(0.1)$ & $3.8(3.4)$ & $1.3(0.0)$ & $11.7(2.5)$ \\
\hline Irradiated & nd & nd & $1.5(0.0)$ & $88.8(7.0)$ & $1.3(0.1)$ & $32.4(7.5)$ \\
\hline \multicolumn{7}{|l|}{ Combahee } \\
\hline Dark & $1.0(0.1)$ & $\sim 100^{\mathrm{a}}$ & $1.0(0.0)$ & $5.0(1.3)$ & $0.8(0.0)$ & $11.9(5.7)$ \\
\hline Irradiated & $2.4(0.8)$ & $\sim 100^{\mathrm{a}}$ & $0.9(0.0)$ & $30.2(4.1)$ & $0.8(0.0)$ & $25.6(1.2)$ \\
\hline \multicolumn{7}{|l|}{ Ashepoo 2} \\
\hline Dark & $1.2(0.2)$ & $\sim 100^{\mathrm{a}}$ & $0.8(0.1)$ & $57.2(0.7)$ & $0.9(0.0)$ & $6.7(2.1)$ \\
\hline Irradiated & $2.5(0.5)$ & $\sim 100^{\mathrm{a}}$ & $0.8(0.0)$ & $99.1(6.0)$ & $0.9(0.0)$ & $23.9(1.2)$ \\
\hline
\end{tabular}


unit carbon production in irradiated treatments increased from $117 \%$ (Combahee experiment) to $209 \%$ (Ashepoo 2 experiment), relative to dark controls. Time course data for $\mathrm{NO}_{2+3}$ concentrations showed a mixed pattern of response, both between treatments and among experiments. Concentrations of $\mathrm{NO}_{2+3}$ showed no significant change over time in the dark treatments in 3 of the 4 experiments, but a significant decrease $(57.2 \%)$ was observed in the Ashepoo 2 experiment. In contrast, concentrations of $\mathrm{NO}_{2+3}$ did show significant decreases over time in the irradiated treatments in 3 of the 4 experiments, with the maximum consumption (99\%) occurring in the Ashepoo 2 experiment. Time course data for $\mathrm{NH}_{4}$ concentrations were only available for the Combahee and Ashepoo 2 experiments. In both instances, $\mathrm{NH}_{4}$ concentrations decreased to below detection limits $\left(0.4 \mu \mathrm{mol} \mathrm{N} \mathrm{^{-1 }}\right)$ within $5 \mathrm{~d}$ of incubation in both irradiated and dark treatments.

\section{DISCUSSION}

The results of this study directly address 2 fundamental aspects of the coupling between photochemical and microbial degradation of terrigenous DOM carried by blackwater rivers to the coastal zone: (1) How does exposure to sunlight affect the balance between anabolic and catabolic metabolism of estuarine bacteria growing on terrigenous DOM? (2) How does photoalteration of this DOM affect the interaction between bacterial carbon and nutrient dynamics? The effects of light exposure on DOM optical properties, DOC and nutrient concentrations are consistent with previous studies, but we observed that the subsequent effects on bacterial metabolism are more complicated than previously considered.

The observed effects of irradiation on DOM from the 3 blackwater rivers sampled in the present study are generally consistent with those of previous studies that have examined the effects of photochemical transformations on terrigenous DOM. The loss of DOC during exposure to $24 \mathrm{~h}$ of simulated sunlight, amounting to $9-17 \%$ of initial DOC concentrations, is in agreement with previous reports of photomineralization (Mopper \& Kieber 2002). Several of these studies (e.g. Miller \& Zepp 1995, Miller \& Moran 1997) have shown that DOC loss and photochemical production of $\mathrm{CO}_{2}$ are correlated with differences in DOM photobleaching among water samples. In this study, differences in the absolute loss of DOC upon irradiation were also strongly correlated with differences in $a_{350}$ during irradiation ( $\mathrm{r}=0.93, \mathrm{n}=8, \mathrm{p}<0.001)$, but losses of $a_{350}$ in irradiated treatments were considerably greater than corresponding decreases in DOC concentrations. This supports the idea that photoreactive DOM has a greater absorptivity than that of the bulk DOM pool (Gao \& Zepp 1998).

There has been considerable interest in DOM photodegradation as a source of inorganic nutrients to aquatic ecosystems since the discovery of photoammonification from humic-rich DOM (Bushaw et al. 1996). Subsequent studies of photoammonification have yielded contradictory results, however, with some studies documenting $\mathrm{NH}_{4}$ production (e.g. Gao \& Zepp 1998, Kieber 2000), but others reporting either no net photoproduction or a loss of $\mathrm{NH}_{4}$ due to irradiation (e.g. Jørgensen et al. 1999, Koopmans \& Bronk 2002). Although irradiation of riverine DOM in this study always resulted in increased concentrations of $\mathrm{NH}_{4}$ (equaling 80 to $180 \%$ of initial values), differences in the magnitude of $\mathrm{NH}_{4}$ production among river samples were not predictable from either initial DON concentrations or DOM optical characteristics. These results thus contrast with those observed for DOC and $a_{350}$ losses, but are consistent with previous observations that photochemical transformations of nitrogen do not appear predictable from any currently measured characteristic of DOM (Grzybowski 2003).

Exposure of riverine DOM to $24 \mathrm{~h}$ of simulated sunlight significantly enhanced bacterial metabolism and rates of DOC utilization, as observed previously in studies conducted with terrigenous DOM (Moran \& Covert 2003). In the present study, irradiation increased rates of bacterial respiration to a greater extent (mean increase of $49 \%$ ) than bacterial growth (mean increase of $28 \%$ ), however, and thus significantly lowered estimates of BGE. These results demonstrate the importance of considering not only the total magnitude of carbon flow to the bacteria, but also its ultimate fate. This reduction in BGE with exposure to sunlight is consistent with the results of Vähätalo et al. (2003) for a humic-rich freshwater lake, but contrasts with those of Reche et al. (1998), who also worked with samples from a freshwater lake. The reason for the contrasting results observed in these 2 freshwater lake studies is unclear, but may be related, in part, to differences in the nature of the DOM between the studies. In the study by Reche et al. (1998), BGE on non-photoaltered DOM was exceptionally low (0.1 to $3.6 \%$ ), compared to values typically observed in freshwater systems ( 20 to $35 \%$ ) (del Giorgio \& Cole 1998).

The most likely explanation for the observed decrease in BGE is a change in the substrates utilized by the bacterial assemblage. Identifiable photoproducts resulting from exposure of humic-rich DOM to sunlight tend to be low-molecular-weight carbonyl compounds (Kieber et al. 1990, Wetzel et al. 1995, Obernosterer et al. 1999, Bertilsson \& Tranvik 2000). The most commonly occurring examples include acetate, acetaldehyde, oxalate, glyoxylate and pyru- 
vate. While bacteria can rapidly assimilate these types of substrates (Miller \& Moran 1997), such compounds likely result in minimal energy yields per substrate consumed during bacterial catabolism (Bertilsson \& Tranvik 1998). In addition, such compounds lack $\mathrm{N}$ or $\mathrm{P}$ and likely provide little for the anabolic synthesis of bacterial biomass. Published data from bacterioplankton growth on defined compounds and natural DOM suggest a positive relationship between growth efficiency and the carbon-normalized degree of substrate reduction (Vallino et al. 1996) as well as a strong correlation between specific growth rate and the relative proportion of aliphatic carbon in the growth media (Sun et al. 1997). While chemical structure is not the only factor affecting substrate use, identified organic photoproducts tend not to be high in either their degree of reduction or aliphatic content. If a significant fraction of the enhanced bacterial growth on irradiated DOM resulted from bacterial utilization of photoproducts similar to those previously identified, an increased BCD and decreased BGE would be expected. This study provides direct experimental evidence for such a decrease during use of photoaltered terrigenous DOM by estuarine bacteria.

Most naturally occurring DOM defies molecular characterization (Benner 2002). It is unlikely that all the low-molecular-weight photoproducts of DOM have been identified. In addition, bacteria in irradiated treatments likely utilized high-molecular-weight compounds that were structurally altered by irradiation, but not transformed into smaller, chemically identifiable compounds (Miller \& Moran 1997). Irrespective of its effect on molecular size, the importance of DOM phototransformations in determining carbon flow and fate during microbial degradation is further supported by the strong interaction between treatment and river effects observed among the 4 experiments of this study. The initial absorptivity $\left(a_{350}\right)$ of the water sample appears to be a key predictor in this regard, as has been observed previously (Miller \& Zepp 1995, Tranvik \& Bertilsson 2001). The relationships observed in the present study expand on previous work by showing that the initial $a_{350}$ of the water sample was important not only for the degree to which DOC concentration and color are lost during irradiation, but also for total carbon flow (BCD) and its relative partitioning between anabolism and catabolism (BGE) during subsequent bacterial growth on photoaltered DOM. The exact form of this relationship, it should be noted, is likely biased by differences in inner filter effects of the DOM among experiments ( $\mathrm{Hu}$ et al. 2002), i.e. given the large sample volumes and constant irradiation intensity used across the experiments, those samples with higher $a_{350}$ values experienced less total light exposure than those with lower $a_{350}$ values, due to self- shading within the sample. Therefore, if these inner filter effects were corrected for, the spread in BCD and BGE response would be even greater that the current relationship indicates.

The shift in bacterial carbon metabolism upon exposure to simulated sunlight was accompanied by a dramatic increase in inorganic nutrient uptake by the bacterial assemblages. Although bacteria were net consumers of inorganic nitrogen and phosphorus in all treatments, irradiation acted to significantly increase this consumption. While many previous studies of photochemical effects on bacterial DOM degradation have employed additions of inorganic nutrients to prevent any possibility of nutrient limitation during experimental incubations (e.g. Miller \& Moran 1997, Moran et al. 2000), the specific prospect of altered nutrient requirements during use of phototransformed DOM has not been examined directly. The one exception to this is a recent report of enhanced nutrient demand in bacterial growth cultures of photoaltered DOM from a humic lake (Vähätalo et al. 2003).

It has been proposed (Bushaw et al. 1996) that the photochemical production of inorganic nutrients, primarily $\mathrm{NH}_{4}$, should increase bacterial degradation of terrigenous DOM. The results of the present study argue, however, for a reversal of causality in such carbon and nutrient interactions. The most likely explanation for enhanced nutrient demand (primarily $\mathrm{PO}_{4}$ ) per unit bacterial carbon production in the irradiated treatments is utilization resulting from bacterial assimilation of carbon-rich photoproducts. Most available evidence suggests that heterotrophic bacteria in coastal environments are primarily limited by nutrient availability (Williams 2000), and spatial patterns of BGE in the coastal zone often follow those of inorganic nutrient concentrations (e.g. Smith \& Kemp 2003). If the photochemical production of bioavailable nutrients were driving enhanced bacterial consumption of DOC, then one might expect this to occur with a higher growth efficiency. Just the opposite was observed, however, lending further empirical support to the proposition that bacterial metabolism and carbon consumption of photochemically altered DOM occurs at the expense of simple carbonyl, or other carbon-rich, compounds.

Addressing the full importance of photochemicalbiological interactions at the scale of the ecosystem requires a detailed analysis of the extent to which photoreactions occur in situ. This includes, among other things, quantifying the extent of light exposure in situ and the relationship between photoreaction rates and in situ spectral irradiance (e.g. Miller et al. 2002). While such analysis is outside the scope of the current study, the results presented here expand on previous studies by examining the consequences of DOM 
phototransformations (to the extent that they occur in situ) on subsequent bacterial dynamics. In this regard, it is clear that the effects of DOM irradiation are best addressed by considering both the magnitude and fate of carbon use by the bacterial community, which requires the measurement of both anabolic and catabolic pathways of bacterial metabolism. Bacterial consumption of DOC greatly increased after irradiation. Bacteria grew at moderately higher specific rates and attained higher biomass, but with a reduced growth efficiency. In contrast, in the absence of irradiation, bacteria consumed less DOC, grew more slowly and attained relatively less biomass, but with a higher growth efficiency. In the presence of an extensive pool of otherwise biologically recalcitrant DOM, enhanced production of bacterial biomass due to irradiation would enhance carbon availability to the food web, regardless of the efficiency with which it is used. The extent to which this is the case thus depends on the extent to which DOM not previously exposed to irradiation can be considered biologically recalcitrant.

Average DOC loss for the dark treatments $(3.9 \pm$ $1.3 \%$ after $5 \mathrm{~d}, 21 \pm 2.4 \%$ after $28 \mathrm{~d}$ ) was higher than losses observed previously for some blackwater rivers draining the coast of the southeastern United States (Moran et al. 1999), but was low relative to losses reported in a recent synthesis of DOC lability (9 to $26 \%$ after 1 to $3 \mathrm{~d}$ incubations) across a range of aquatic environments (del Giorgio \& Davis 2003). This suggests that DOM exported by the rivers of the St. Helena basin is likely less bioavailable than that in many other aquatic environments. Bacterial growth and DOC consumption observed in the dark treatments of the present study were not insignificant, however. Specific growth rates were similar to those generally observed in estuarine environments (White et al. 1991). DOC concentrations exhibited a steady decrease throughout the $28 \mathrm{~d}$ bioassay (amounting to $21.0 \pm 2.4 \%$ of initial values) and showed little evidence of slowing its decline at the end of the incubation. This is consistent with observations that DOCnormalized $\mathrm{O}_{2}$ consumption by bacteria was roughly linear for up to $\sim 60 \mathrm{~d}$ in 3 blackwater rivers from the SE United States (Moran et al. 1999). Thus, given enough time, estuarine bacteria would appear capable of utilizing an appreciable quantity of riverine DOC at growth efficiencies within the range typically encountered in estuarine communities (del Giorgio \& Cole 1998).

In contrast to the slow but steady loss of DOC in the dark treatments, DOC losses in the irradiated treatments exhibited a distinctly biphasic pattern which was best described by a 2-pool multi-G model (Berner 1980). Patterns of DOC losses in irradiated treatments are clearly consistent with the photoproduction of sub- strates that were rapidly consumed within days, at which point DOC losses returned to rates similar to, or less than, those observed throughout the dark bioassays. While this initial pulse of rapid DOC consumption resulted in a modest increase in bacterial biomass, the fate of most of the DOC use was largely the respiratory loss to $\mathrm{CO}_{2}$.

Recent experimental work has demonstrated that photochemical and microbial degradation can compete, to a large extent, for the same components of terrigenous DOM (Obernosterer \& Benner 2004). The results of the present study indicate that phototransformations of terrigenous DOM produce substrates that stimulate the respiratory loss of this DOM more than its incorporation into bacterial biomass. Taken together, these observations suggest it is unlikely that photochemical transformations of humic-rich DOM substantially supplement the pool of substrates available for transfer within the food web of coastal ecosystems. Conceptual models of photochemical-biological interactions thus need to differentiate photochemical effects on DOM dynamics from effects on food web dynamics. Irradiation of terrigenous DOM is a 'positive' for bacterial processing of DOM in that total carbon utilization (respired plus assimilated) increases. Irradiation of terrigenous DOM is a 'negative' for coastal food webs, however, in that both direct photomineralization and a shift towards the respiration of photoaltered DOM by bacteria will result in less carbon available for transfer to the next trophic level. Moreover, this shift in carbon utilization by bacteria is coupled to a greatly enhanced demand for inorganic nutrients, which may further affect the trophic dynamics of the coastal zone.

Acknowledgements. We thank the Biogeochemistry Group at the University of South Carolina for insightful discussions during the preparation of this manuscript and S. Walker for help in drafting Fig. 1. This research was supported by funding from the National Science Foundation (OCE-0096102).

\section{LITERATURE CITED}

Amon RMW, Benner R (1996) Bacterial utilization of different size classes of dissolved organic matter. Limnol Oceanogr 41:41-51

Armstrong FA, Williams PM, Strickland JDH (1966) Photooxidation of organic matter in seawater by ultraviolet radiation, analytical and other applications. Nature 211: 481-483

Benner R (2002) Chemical composition and reactivity. In: Hansell DA, Carlson CA (eds) Biogeochemistry of marine dissolved organic matter. Academic Press, New York, p 59-90

Benner R, Biddanda B (1998) Photochemical transformations of surface and deep marine dissolved organic matter: effects on bacterial growth. Limnol Oceanogr 43: $1373-1378$ 
Berner RA (1980) Early diagenesis: a theoretical approach. Princeton University Press, Princeton, NJ

Bertilsson S, Tranvik LJ (1998) Photochemically produced carboxylic acids as substrates for freshwater bacterioplankton. Limnol Oceanogr 43:885-895

Bertilsson S, Tranvik LJ (2000) Photochemical transformation of dissolved organic matter in lakes. Limnol Oceanogr 45:753-762

Brinkmann T, Horsch P, Sartorius D, Frimmel FH (2003) Photoformation of low-molecular-weight organic acids from brown water dissolved organic matter. Environ Sci Technol 37:4190-4198

Bushaw KL, Zepp RG, Tarr MA, SchulzJander D and 5 others (1996) Photochemical release of biologically available nitrogen from aquatic dissolved organic matter. Nature 381:404-407

del Giorgio PA, Cole JJ (1998) Bacterial growth efficiency in natural aquatic systems. Annu Rev Ecol Syst 29:503-541

del Giorgio PA, Davis J (2003) Patterns in dissolved organic matter lability and consumption across aquatic ecosystems. In: Findlay S, Sinsabaugh R (eds) Aquatic ecosystems: interactivity of dissolved organic matter. Elsevier Science, New York, p 399-424

Francko DA, Heath RT (1982) UV-sensitive complex phosphorus: association with dissolved humic material and iron in a bog lake. Limnol Oceanogr 43:1814-1825

Gao HZ, Zepp RG (1998) Factors influencing photoreactions of dissolved organic matter in a coastal river of the southeastern United States. Environ Sci Technol 32:2940-2946

Grzybowski W (2003) Short-term sunlight irradiation of organic matter dissolved in lake water increased its susceptibility to subsequent biooxidation. Acta Hydrochim Hydrobiol 30:285-292

Hedges JI, Keil RG, Benner R (1997) What happens to terrestrial organic matter in the ocean? Org Geochem 27: 195-212

Hernes PJ, Benner R (2002) Transport and diagenesis of dissolved and particulate terrigenous organic matter in the North Pacific Ocean. Deep-Sea Res I 49:2119-2132

Hopkinson CS, Smith EM (2005) Estuarine respiration: an overview of benthic, pelagic and whole system respiration. In: del Giorgio PA, Williams PJleB (eds) Respiration in aquatic ecosystems. Oxford University Press, Oxford, p 122-146

Hopkinson CS, Vallino JJ, Nolin A (2002) Decomposition of dissolved organic matter from the continental margin. Deep-Sea Res II 49:4461-4478

$\mathrm{Hu}$ CM, Muller-Karger FE, Zepp RG (2002) Absorbance, absorption coefficient, and apparent quantum yield: a comment on common ambiguity in the use of these optical concepts. Limnol Oceanogr 47:1261-1267

Jørgensen NOG, Tranvik LJ, Berg GM (1999) Occurrence and bacterial cycling of dissolved nitrogen in the Gulf of Riga, the Baltic Sea. Mar Ecol Prog Ser 191:1-18

Kieber DJ (2000) Photochemical production of biological substrates. In: de Mora SJ, Demers SJS, Vernet M (eds) The effects of UV radiation in the marine environment. Cambridge University Press, Cambridge, p 130-148

Kieber RJ, Zhou XL, Mopper K (1990) Formation of Carbonylcompounds from UV-induced photodegradation of humic substances in natural-waters - fate of riverine carbon in the sea. Limnol Oceanogr 35:1503-1515

Koopmans DJ, Bronk DA (2002) Photochemical production of dissolved inorganic nitrogen and primary amines from dissolved organic nitrogen in waters of two estuaries and adjacent surficial groundwaters. Aquat Microb Ecol 26: 295-304
Lee S, Fuhrman JA (1987) Relationships between biovolume and biomass of naturally-derived marine bacterioplankton. Appl Environ Microbiol 52:1298-1303

Miller WL, Moran MA (1997) Interaction of photochemical and microbial processes in the degradation of refractory dissolved organic matter from a coastal marine environment. Limnol Oceanogr 42:1317-1324

Miller WL, Zepp RG (1995) Photochemical production of dissolved inorganic carbon from terrestrial organic-mattersignificance to the oceanic organic-carbon cycle. Geophys Res Lett 22:417-420

Miller WL, Moran MA, Sheldon WM, Zepp RG, Opshal S (2002) Determination of apparent quantum yield spectra for the formation of biologically labile photoproducts. Limnol Oceanogr 47:343-352

Mopper K, Kieber DJ (2002) Photochemistry and the cycling of carbon, sulfur, nitrogen and phosphorus. In: Hansell DA, Carlson CA (eds) Biogeochemistry of marine dissolved organic matter. Academic Press, New York, p 456-508

Moran MA, Covert JS (2003) Photochemically mediated linkages between dissolved organic matter and bacterioplankton. In: Findlay S, Sinsabaugh R (eds) Aquatic ecosystems: interactivity of dissolved organic matter. Elsevier Science, New York, p 243-262

Moran MA, Zepp RG (1997) Role of photoreactions in the formation of biologically labile compounds from dissolved organic matter. Limnol Oceanogr 42:1307-1316

Moran MA, Sheldon WM, Sheldon JE (1999) Biodegradation of riverine dissolved organic carbon in five estuaries of the southeastern United States. Estuaries 22:55-64

Moran MA, Sheldon WM, Zepp RG (2000) Carbon loss and optical property changes during long-term photochemical and biological degradation of estuarine dissolved organic matter. Limnol Oceanogr 45:1254-1264

Obernosterer I, Benner R (2004) Competition between biological and photochemical processes in the mineralization of dissolved organic carbon. Limnol Oceanogr 49:117-124

Obernosterer I, Kraay G, de Ranitz E, Herndl GJ (1999) Dynamics of low molecular weight carboxylic acids and carbonyl compounds in the Aegean Sea (eastern Mediterranean) and the turnover of pyruvate. Aquat Microb Ecol 20:147156

Opsahl S, Benner R (1997) Distribution and cycling of terrigenous dissolved organic matter in the ocean. Nature 386:480-482

Opsahl S, Benner R (1998) Photochemical reactivity of dissolved lignin in river and ocean waters. Limnol Oceanogr 43:1297-1304

Parsons TR, Maita Y, Lalli CM (1984) A manual of chemical and biological methods for seawater analysis. Pergamon Press, New York

Porter KG, Feig Y (1980) The use of DAPI for identifying and counting aquatic microflora. Limnol Oceanogr 25:943-948

Reche I, Pace ML, Cole JJ (1998) Interactions of photobleaching and inorganic nutrients in determining bacterial growth on colored dissolved organic carbon. Microb Ecol 36:270-280

Seitzinger SP, Sanders RW (1997) Contribution of dissolved organic nitrogen from rivers to estuarine eutrophication. Mar Ecol Prog Ser 159:1-12

Smith EM, Kemp WM (2003) Planktonic and bacterial respiration along an estuarine gradient: responses to carbon and nutrient enrichment. Aquat Microb Ecol 30:251-261

Smith SV, Hollibaugh JT (1993) Coastal metabolism and the oceanic organic carbon balance. Rev Geophys 31:75-89

Solórzano L (1969) The determination of ammonium in nat- 
ural waters by phenol-hypochlorite method. Limnol Oceanogr 14:799-801

Stepanauskas R, Jorgensen NOG, Eigaard OR, Zvikas A, Tranvik LJ, Leonardson L (2002) Summer inputs of riverine nutrients to the Baltic Sea: bioavailability and eutrophication relevance. Ecol Monogr 72:579-597

Sun L, Perdue EM, Meyer JL, Weis J (1997) Use of elemental composition to predict bioavailability of dissolved organic matter in a Georgia river. Limnol Oceanogr 42:714-721

Tranvik LJ, Bertilsson S (2001) Contrasting effects of solar UV radiation on dissolved organic sources for bacterial growth. Ecol Lett 4:458-463

Vähätalo AV, Salonen K, Munster U, Jarvinen M, Wetzel RG (2003) Photochemical transformation of allochthonous organic matter provides bioavailable nutrients in a humic lake. Arch Hydrobiol 156:287-314

Editorial responsibility: Gerhard Herndl, Den Burg, Texel, The Netherlands
Vallino JJ, Hopkinson CS, Hobbie JE (1996) Modeling bacterial utilization of dissolved organic matter: optimization replaces Monod growth kinetics. Limnol Oceanogr 41: 1591-1609

Wetzel RG, Hatcher PG, Bianchi TS (1995) Natural photolysis by ultraviolet irradiance of recalcitrant dissolved organic matter to simple substrates for rapid bacterial metabolism. Limnol Oceanogr 40:1369-1380

White PA, Kalff J, Rasmussen JB, Gasol JM (1991) The effect of temperature and algal biomass on bacterial production and specific growth rate in freshwater and marine habitats. Microb Ecol 21:99-118

Williams PJleB (2000) Heterotrophic bacteria and the dynamics of dissolved organic matter. In: Kirchman DL (ed) Microbial ecology of the oceans. Wiley-Liss, New York, p 153-200

Submitted: October 29, 2004; Accepted: March 10, 2005

Proofs received from author(s): June 20, 2005 